\title{
Determinants of Work-Family Balance: An Empirical Study of Accounting Professionals in Sri Lanka
}

\author{
HHDNP Opatha \\ Senior Professor \\ University of Sri Jayewardenepura \\ Hasini Perera \\ Senior Executive \\ Ernst \& Young-Chartered Accountants
}

\begin{abstract}
The main objective of the research was to identify the most important three factors which determine work-family balance according to a preliminary investigation of the perception of a selected group of actual Sri Lankan professionals in Accountancy and to investigate whether they significantly contribute to the work-family balance of Sri Lankan professionals in Accountancy. Also the research was designed to investigate whether there is a significant difference between male accounting professionals and female accounting professionals with regard to the degree of work-family balance; and to determine the degree of combined effect of the most important three factors on the variability of work-family balance of Sri Lankan professionals in Accountancy. The participants were the Accountancy professionals in Sri Lanka, (members of ICASL, CIMA and ACCA) who were employed during the time of the study. The final sample consisted of fifty four (56\%) males and forty two (44\%) females whose average age was 39.4 years. The type of investigation of this study was correlational and differential rather than causal, because the study attempted to analyze the relationship between the dependent variable and independent variables. The study was analytical in nature. Further this research was not an experiment and therefore manipulation of data and control of independent variables were not done. The study was conducted in the natural environment and researcher's interference was minimal under normal circumstances. As the data collection was done within a particular time period and there was no subsequent extension of the research, the study was cross sectional in nature. The unit of analysis was individual and covered members of ICASL, CIMA and ACCA.
\end{abstract}

The results of the study showed that work-family balance is positively related to time management, nature of the spouse and understanding of the strategies available for work-family balance. The individual variable which had the highest impact on work-family balance of Accounting Professionals in Sri Lanka is the understanding the strategies available for workfamily balance. Further it was found that there is no significant difference between male professionals and female professionals with regard to work-family balance.

Key Words: Work-Family Balance, Time Management, Nature of the Spouse, Accounting Professionals 


\section{Introduction}

It has generally been observed that employees who have families encounter increasingly a challenge called Work-Family Balance (WFB). The difficulty of balancing work and family life is an emerging challenge for both employees and employers. During the past recent years, Sri Lanka has undergone several changes in the economic, work, and social spheres. Market competition and mass entry of women into labour market are two main changes occurred in the economic sphere, and higher concern of increasing productivity, working beyond the normal working hours ( 08 hours), increased number of women employed and promoted as managers, and increased application of new technology are four major changes occurred in work sphere. In the social sphere the major changes occurred are increased number of dual-career couples, increased number of nuclear families, and increased number of sandwich generation. These changes indeed resulted in increasing the difficulty of balancing work and family life.

If WFB is not in existence, there will be imbalance resulting in conflict between work life and family life. Imbalance occurs when work life and home life directly conflict with one another, due to toiling long hours and an inability to meet commitments at home, or to spending too much time at home, resulting in a failure to complete responsibilities at work (Nelson and Lyubomirsky, 2015). Work-Family Conflict (WFC) is defined by Greenhaus and Beutell in 1985 as a conflict between the different roles played by the same person, and this conflict takes three forms: time conflicts, conflict due to tension between roles and behavioural conflicts (St-Amour, Laverdure, Devault, and Manseau, 2007).

To have a family is highly valued according to Sri Lankan cultural traditions. A person with a family including children is always appreciated and hence many professionals tend to commit to a family relationship while pursuing a career. It seems as per our observations that increasingly Sri Lankan employees including professionals are encountering conflicts between their work life and family life. WFC can result in a number of dysfunctional outcomes, including burnout, decrease in mental well-being, deteriorating relationships, and job and life dissatisfaction (McFarland, 2004). While work-life imbalance is not a new problem, it has received more attention this decade than ever before, and this problem poses risks to workers' well-being as well as to organizational performance (Lowe, 2006). Lowe (2006) found that one of the most common HR challenges experienced by employers is work-life balance (the other one is employee stress), and yet fewer than 1/3 of employers surveyed took any action to address this issue. Conflict between work and home life has been linked to job dissatisfaction and turnover and increasingly organizations are using work-life balance initiatives such as flexible work arrangements, leave arrangements, dependent care assistance, and general services to recruit and retain key personnel (Smith and Gardner, 2007). It is generally agreed that work-life balance is important for an individual's psychological well-being (Rantanen, Kinnunen, Mauno, and Tillemann, 2011). Based on an extensive literature review of previous research studies, StAmour et al (2007) developed a theoretical framework of WFB according to which WFC has bad consequences or negative impacts on family (decresaed socialization, deterioration of lifestyle practices- food, exercise etc., adaptation problems, reduced merital satisfaction, and reduced ability to transmit values, culture), work (reduced work satisfaction, absenteeism, increased employee turnover, and demotivation), and health (stress, buronout, fatique, tension and depression, migraines, and cardiovascular diseases). A majority of college and university students say that attaining a balance between personal life and work life is a primary career goal, 
and they want 'a life' as well as a job (Robbins and Judge, 2013). Work-family conflicts may cause many consequences such as high stress, less concentration on obligations towards family, high alcoholism, high drug addiction, high absenteeism, and high rate of divorces (Opatha, 2015).

According to experts, WFC is less of a personal issue and more of a public and organizational policy issue (McFarland, 2004). Leading employers are recognizing that positive work-life outcomes for employees-from achieving work-life balance to the satisfactions of challenging work and career development-are key ingredients of a successful business strategy (Lowe, 2006). WFC has significant consequences for all social actors (health, social and economic impacts), resulting in the need for government to review the roles currently played by various actors, as well as the adaptation of public policy, in order to bring these factors in line with the new realities of professional activity and family life (St-Amour et al, 2007). Organizations want to attract and retain the most appropriate employees and therefore they have to assist employees to achieve this balance (Opatha, 2015). Hence, to understand determinants of WFB is of importance to employees and employers as well.

\section{Problem Statement, Research Questions, and Research Objectives}

Considerable research has been directed toward trying to understand the antecedents of WFC in the hope that a better understanding of the causes of WFC will help people avoid it (McFarland, 2004). Sri Lankan studies about grievances of employees (Opatha, 1994; Opatha, 2005; Akuratiyagamage and Opatha, 2004) revealed that the job itself causes many grievances and created the highest degree of grievances. However, Sri Lankan studies in respect of determinants of WFB are hardly found. Among the groups of professionals, accounting professionals are of very imporance as they are personnel who engage in accounting. Accounting is a highly respected and established profession and it is the act of collecting, processing, reporting, analyzing, interpreting, and projecting financial information (Dupree and Marder, 1984). It is interesting to conduct an empirical study on WFB of accountants. An accountant is one who designs systems; supervises bookkeepers; prepares, analyzes, and interprets financial reports; audits accounting records; and/or performs other complex accounting activities (Dupree and Marder, 1984). There is a gap in the empirical knowldge in respect of factors which determine WFB of accounting professionals in Sri Lanka. As far as Sri Lanka is concerned theoretical arguments or empirical research findings with regard to dynamics of WFB of Accounting Professionals are unavailable. The problem statement addressed in this study is as follows:

What are the three most important factors which determine work-family balance of Sri Lankan accounting professionals according to their perception, their impact on work-family balance and does work-family balance get differed by gender?

Specifically the following research questions were addressed:

1. What are the most important three factors which determine work-family balance of Sri Lankan accounting professionals according to the perception of a selected small group of highly qualified and experienced accounting professionals?

2. Do these three factors positively and significantly relate to work-family balance?

3. Do these three factors have a significant positive joint impact on work-family balance? 
4. Is there a significant difference between male accounting professionals and female accounting professionals with regard to the degree of work-family balance?

An attempt was made to achieve the following research objectives which were derived from the above formulated research questions:

1. To determine the most important three factors affecting work-family balance of Sri Lankan accounting professionals according to the perception of a selected small group of highly qualified and experienced accounting professionals.

2. To investigate whether these three factors positively and significantly relate to workfamily balance.

3. To establish that these three factors have a significant positive joint impact on workfamily balance.

4. To inverstigate whether there is a significant difference between male accounting professionals and female accounting professionals with regard to the degree of workfamily balance.

\section{Conceptualization of WFB}

The concept of WFB is indeed an abstract one and it is possible to define it by different scholars differently. Also there are different terms associated or used interchangably with WFB. WorkLife Balance, Work-Family Fit and Work-Family Integration are three alternative terms. It is possible that a professional has a life that has several aspects including work, family, social, spiritual, and other ones. In this study, work aspect and family aspect were considered.

Greenhaus et al (2003, as in Rantanen et al, 2011) define WFB as the extent to which an individual is equally engaged in-and equally satisfied with-his or her work and family role. Sekaran (1992) has defined work-life balance as healthy management of the work and nonwork spheres of life without experiencing undue stress. Work-life balance is the ability to meet commitments at home and at work (Guest, 2002, as in Nelson and Lyubomirsky, 2015). WFB is defined as the degree to which one fulfils demands coming and responsibilities arising from his or her employment and family (adapted from Opatha and Teong, 2014). According to Nelson and Lyubomirsky (2015) achieving work-life balance involves finding a happy medium in which one can meet the responsibilities of both work and home.

If an accounting professional fulfils the respective demands in the way that generates satisfaction, it is possible to say that he or she has a right balance between work and family. If an accounting professional cannot meet the respective demands and the relevant parties are dissatisfied, it is possible to say that he or she has an imbalance between work and family. Working definition of WFB is ability of an accounting professional to meet his/her employer's expectations and his/her family members' expectations to the extent that makes them happy. It involves meeting commitments at both work and home through the use of sufficient time, energy and competencies.

\section{Determinants of WFB}

Determinants of WFB include factors that determine WFB. Surprisingly, our literature has more to say about antecedents and consequences of work-family conflcit and less on strategies to 
effectively manage it (McFarland, 2004). Work life can be a problem or barrier to family life or vice versa. Researchers acknowledged the reciprocal nature of the relationship between work and family, and they adopted a bidirectional perspective of WFC (St-Amour et al, 2007). The conflict does not operate in one direction, and family sometimes interferes with work (FIW), and work can interfere with family (WIF) (McFarland, 2004). Individuals claim to feel more WIF than FIW (St-Onge et al, 2002, as in St-Amour et al, 2007). McFarland (2004, p. 48) writes:

"Some of the things that lead to conflcit are fairly intuitive. For example, working long hours, long commutes to and from work, workload, lack of management support, job involvement, and level of importance assigned to one's work, all predict the extent to which WIF. Further, marital status, number of children, level of importance assigned to family roles, and lack of family support all contribute to FIW."

Further, personality types such as neuroticism, type A tendency, and negative affectivity, and age affect WFC according to McFarland (2004). One determinant of WFC is number of multiple roles to be performed by the professional. WFC occurs when individuals have to perform multiple roles: worker, spouse, and parent according to Greenhaus and Beutell (1985).

Senecal, Vallerand, and Guay (2001) developed a model called a motivational model in respect of antecedents and outcomes of work-family conflict. According to the model, feeling valued by one's partner, feeling autonomy-supported by one's employer, motivation toward family activities, motivation toward work, and family alienation are antecedents of work-family conflict and feelings of emotional exhaustion are coutcomes of work-family conflict. The model proposes that high levels of self-determined family and work motivation both contribute to reduce family alienation, which in turn influences to reduce the experience of work-family conflicts.

\section{Determinants of WFB As Perceived by Sri Lankan Accounting Professionals}

For this study, a popular technique called Nominal Group Technique (NGT) was utilized in order to identify determinants of WFB and prioritize them according to the perception of a selected group of Sri Lankan accounting professionals. Nominal Group Technique (NGT) is a group method of drawing out ideas from people on a specific topic (Werther, Davis, Shwind, Das, and Miner, 1985). NGT is a good technique to apply for employee training needs assessment and prioritizing training needs too (Opatha, 2009). McShane et al (2008) define the NGT as a structured team decision-making process whereby team members independently write down ideas, describe and clarify them to the group, and then independently rank or vote on them. The NGT can be viewed as a process that has five steps, which are the purpose of gathering, silent idea generation, giving ideas in round-robin fashion, comments and clarification, and voting (Werther et al, 1985; Opatha, 2015). The NGT tends to generate more and better-quality ideas compared with traditionally interacting and possibly brainstorming groups (Frankel, 1987 and Barki and Pinsonneault, 2001 as in McShane, Glinow, and Sharma, 2008).

A priliminary study through the use of NGT was performed using a group of twenty Sri Lankan accounting professionals working for different companies in Sri Lanka during the month of September in the relevant year of data collection. The names of the respective companies are Ernst \& Young, Pricewaterhouse Coopers, KPMG, BDO Partners, Sri Lankan Airlines, and Sri 
Lanka Accounting and Auditing Standards Monitoring Board. To ensure the confidentiality of information, the names of the respondents were not disclosed. First they were requested to identify the factors that would contribute to WFB according to their perception. Then, the collected data were analysed and a list of factors was prepared. Based on the list, the group members were requested to prioritize the identified factors. The list contained the following factors:

1. Understanding the strategies available for WFB

2. Commitment to work

3. Leadership style of the organization

4. Distance between home and work place

5. Workload including targets

6. Superior's willingness to delegate work to subordinates

7. Organization's willingness and effort to train the subordinates

8. Time management including clear division of one's time for both work and family life

9. Nature of spouse (selecting a suitable partner and mutual understaning, patience and support from the spouse)

10. Planning oneself based on one's SWOT without blindly following others

11. Time allocation for family

12. Management of stress

13. Corporation from co-workers

14. Positive attitude towards family

15. Adaptability

16. Flexible work arrangements (flex time, telecommuting, part time, compressed work schedules, job sharing etc.)

17. Leave arrangements

18. General services (e.g. child care and dependent care assistance, counselling etc.)

19. Resources and facilities to perform the job

20. Availability of support from relatives

21. Possibility of employing a servent

22. Understanding of the demands, responsibilities and expectations of all the relevant parties at work and family

23. Availability of getting advice from right persons and materials

Out of the above identified factors, the most important three factors were 1,8 , and 9 respectively (as per the results of prioritizing given by the NGT members).

\section{Research Framework}

Reearch framework or conceptual framework for this study was built by using the most important three factors of WFB as per the perception of 20 Sri Lankan highly qualified and experienced accounting professionals (based on the results of the NGT).

Work-Family Balance refers to ability of an accounting professional to meet his/her employer's expectations and his/her family members' expectations to the extent that makes them happy. It involves the degree to which a particular accounting professional is successful in meeting both work commitments and family commitments. This was the variable of the primary interest to the 
researchers as they were interested in establishing the dynamics of WFB. Hence it was labelled as the dependent variable of this study. Expectations of parties at both work and family need to be considered so as to be reflective of the realities of WFB.

Time Management refers to the ability possessed by the professional in accounting to understand and engage in management of his or her time. When the professional has no ability to understand and engage in management of time he or she becomes unable to meet all the demands which come from the employment and family. At least some of the demands cannot be fulfilled and also it is possible that fulfilling the demands does not occur to the satisfaction of the relevant parties. Complaints and grievances from the spouse, the children, the parents, the superior, the subordinates and the customers occur. Consequently the professional's contributions to smooth running of family affairs and work affairs become low or inadequate. On the other hand, if the professional has high ability to understand and engage in management of time he or she will be able to meet all the demands which come from the employment and family resulting in balance between work life and family life. According to the perceptual prioritization of the nominal group members, this variable is the most important factor affecting WFB. This variable was considered in this study as a dynamic of WFB, and therefore it was labeled as an independent variable. The higher the ability of the accounting professional in management of time, the higher the WFB is. Based on these arguments, the first hypothesis of this study is formulated as follows:

Hypothesis 1: Time management is significantly and positively related to WFB.

Nature of the Spouse refers to disposition or sort of the life partner selected by the professional. Positive nature of the spouse exhibits high levels of mutual understanding, patience and support given to the professional in family life enabling him or her to fulfill the responsibilities to the level that satisfies the relevant parties. A positive spouse has real love to his or her life partner and is ready to scarify time, energy and other resources for advancement and pleasure of the life partner. Positive nature of the spouse will lead to the professional to create or maintain workfamily balance. According to the perceptual prioritization of the nominal group members, this variable was the second most important factor affecting WFB. This variable was also considered in this study as a dynamic of WFB, and hence it was labeled as an independent variable. When the nature of spouse is positive, WFB is high. Based on these arguments, the second hypothesis of this study is as follows:

Hypothesis 2: The more positive the nature of the spouse, the higher the WFB is.

Understanding the Strategies available for Work-Family Balance refers to the degree to which the professional in accounting knows about techniques, tools etc in respect of work-family balance. The greater the understanding of the available strategies for work-family balance the greater the chance of creating and maintaining work-family balance. A professional with right and adequate understanding of the strategies available for WFB will have a high tendency to apply some of them and this application will result in good degree of WFB. This variable was the third most important factor that would affect WFB according to the perceptual prioritization of the nominal group members. This variable was considered in this study as the third dynamic of WFB, and therefore it was labeled as an independent variable. The higher the understanding of the strategies available for WFB, the higher the WFB will be. Thus, understanding the strategies 
available for WFB is likely to have a positive relationship with WFB. The third hypothesis is below.

Hypothesis 3: Degree of understanding of the strategies available for WFB and the degree of WFB are significantly and positively related.

Joint impact of the above three variables on the degree of WFB refers to simultaneous effect of the three-independent variables on WFB. Time management, nature of the spouse, and understanding the strategies available for WFB were assumed as independent variables that positively affect WFB. Hence it is argued that these three variables will explain jointly a significant percentage in the variability of WFB. Thus, the fourth hypothesis for the study is as follows:

Hypothesis 4: Time management, nature of the spouse, and understanding the strategies available for WFB will jointly and significantly explain the variance in the degree of WFB.

Gender refers to the state of being male or female (Oxford Dictionary). It was generally accepted in the society that preparation of meals for family members, house cleaning, and gardening are the tasks assigned to the wife and providing food and other necessities, furnishing the home, doing external affairs, and providing protection for family members are the tasks assigned to the husband. There is a natural critical task to be performed by the wife, i.e. raising children. In case of modern female professionals there is no change happened to the traditional tasks to be performed by the wife. The modern wife who is a professional is supposed to perform the traditional tasks, and therefore she will encounter a bigger challenge over having work-family balance. Hence it is possible to argue that male accountancy professionals and female accountancy professionals get differed in terms of the degree of work-family balance. This variable was not considered as a dynamic of WFB in this study but it was considered as a variable that would differentiate between the two groups, i.e. male accounting professionals and female accounting professionals with regard to the degree of WFB. The above arguments lead to formulate a hypothesis as follows:

Hypothesis 5: There is a significant difference between male accounting professionals and female accounting professionals with regard to WFB.

Relevant schematic diagram is shown in Figure 1. Time management, nature of the spouse, and understanding the strategies available for WFB are independent variables which are assumed to have significant influences on the dependent variable, i.e. WFB. 
Figure 1: Schematic Diagram of the Research Framework

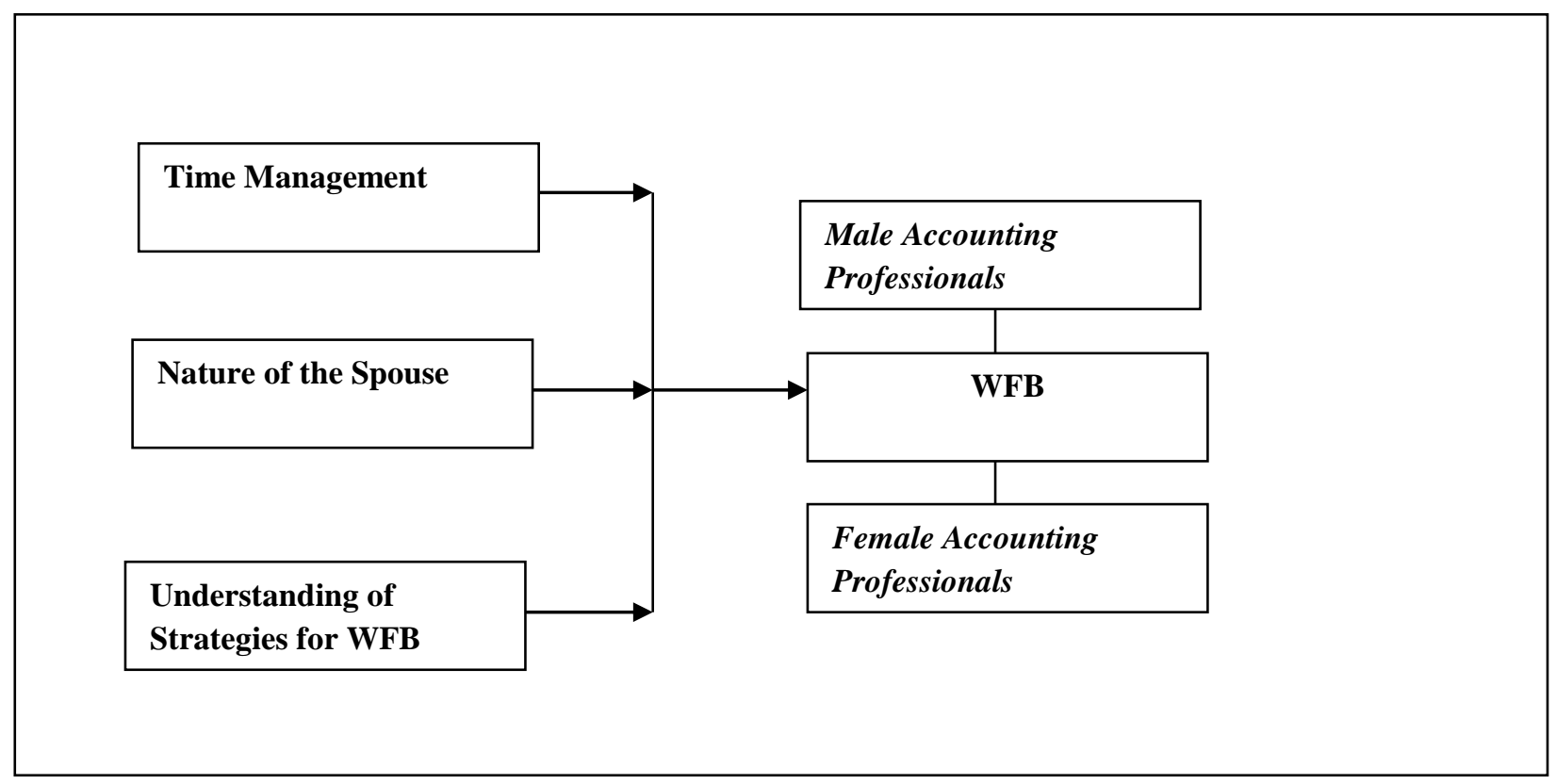

\section{Study Design \\ Method}

The researchers were interested in investigating whether time management, nature of spouse, and understanding of strategies for WFB relate to perceptual degree of WFB and a significant difference exists between male accounting professionals and female accounting professionals with regard to WFB, rather than establishing definite cause $\rightarrow$ effect relationships among the variables. The type of investigation of this study was, therefore, correlational rather than causal. Because an attempt was made to analyse the relationships and difference between the dependent variable and the independent variables in this study, nature of this study was analytical or hypotheses testing. Because the data for this study were collected at a single point in time not having data collection at different points of time the study was cross-sectional in time horizon (Sekaran, 1992; Zikmund, 2000). This was an appropriate strategy when the main focus of the study was considered. A self-administered questionnaire was prepared and used to collect data for the purpose of achieving the objectives of this study, and therefore, the researcher interference on normal flow of events was minimal. Because the researchers were interested in ascertaining the degree of WFB of Sri Lankan accounting professionals and its main dynamics, the unit of analysis for this study was each individual accounting professional. The participants were the Accountancy professionals in Sri Lanka, who were being employed during the time of the study. Each member had the equal chance in getting selected to the sample. The present analysis was limited to 96 respondents who were married, dual earners and had at least one child. These criteria were established to ensure that all respondents have at least moderate level of family responsibilities. The final sample consisted of fifty four (56\%) males and forty two (44\%) females whose average age was 39.4 years. All were married and had children. The majority of 
the sample was accountants at private companies $(61.4 \%)$ and the rest of respondents were audit managers, Chief Financial Officers and bankers.

\section{Operationalization}

The four variables including the dependent variable under the study were constructs and a sufficient attempt was made to operationally defining the constructs so that they became measurable by looking at the faces or properties denoted. Most of the indicators were derived from Opatha, 2010 and Opatha and Teong (2014). The relevant indicators are given in Exhibit 1.

Exhibit 1: The Indicators of Variables Identified

\begin{tabular}{|c|c|}
\hline Variable & Indicators \\
\hline Work-family balance & $\begin{array}{l}\text { 1. Complaints or grievances from your spouse regarding what } \\
\text { the other partner is supposed to do at home } \\
\text { 2. Frequency of such complaints } \\
\text { 3. Complaints or grievances from your children about your } \\
\text { inability to live with them } \\
\text { 4. Frequency of such complaints } \\
\text { 5. Parents' contentedness towards your behavior of meeting } \\
\text { their responsibilities } \\
\text { 6. Contribution to smooth running of family affairs } \\
\text { 7. Relationship with your close relatives } \\
\text { 8. Job performance } \\
\text { 9. Your superior and top management's view on your job } \\
\text { performance } \\
\text { 10. Complaints from peers about your behavior at work } \\
\text { 11. Frequency of complaints } \\
\text { 12. Client's contentedness about your performance in meeting } \\
\text { their requirements } \\
\text { 13. Being a role model to your subordinates to follow }\end{array}$ \\
\hline Time management & $\begin{array}{l}\text { 1. Understanding your time wasters } \\
\text { (E.g.: Travelling, non-essential phone chats, personal } \\
\text { disorganization, try to get perfection, unproductive meetings } \\
\text { etc.) } \\
\text { 2. Adopting any strategies/tactics to handle wasters } \\
\text { (E.g.: Limit travelling, manage the telephone effectively, get } \\
\text { organized properly, deal with perfection intelligently, } \\
\text { manage your relationships properly etc) } \\
\text { 3. Adopting any techniques to manage your time } \\
\text { (E.g.: ABC analysis, Time log, To-do lists etc) } \\
\text { 4. Meeting the deadlines of your assignments without working } \\
\text { many hours at night or slipping other work } \\
\text { 5. Your interest to meet the deadlines } \\
\text { 6. Your ability to estimate about how quickly something can } \\
\text { be done } \\
\text { 7. Your ability to make time-related decisions based on } \\
\text { concrete knowledge of how long it has taken for you to do a }\end{array}$ \\
\hline
\end{tabular}




\begin{tabular}{|c|c|}
\hline & $\begin{array}{l}\text { similar thing in the past } \\
\text { 8. Possibility to complete more things within a shorter period } \\
\text { compared to your peers } \\
\text { 9. Number of things that you have postponed or given up in } \\
\text { your life so far } \\
\text { 10. Time consciousness }\end{array}$ \\
\hline Nature of the spouse & $\begin{array}{l}\text { 1. Employed/ unemployed } \\
\text { 2. Spouse's aspiration to have a career rather than a job } \\
\text { 3. Patience } \\
\text { 4. Spouse's understanding } \\
\text { 5. Support given by the spouse } \\
\text { 6. Career objectives } \\
\text { 7. Spouse's conflict handling style } \\
\text { 8. Enthusiasm to have a good balance between work and } \\
\text { family }\end{array}$ \\
\hline $\begin{array}{l}\text { Understanding the } \\
\text { strategies available } \\
\text { for work-family } \\
\text { balance (Opatha and } \\
\text { Teong, 2014) }\end{array}$ & $\begin{array}{l}\text { 1. Develop a positive attitude about work-family balance } \\
\text { 2. Understand fully demands, expectations, and responsibilities } \\
\text { of all relevant parties at work and at family } \\
\text { 3. Gain understanding and patience of family members } \\
\text { 4. Divide the time between family life and work life } \\
\text { 5. Not to work on holidays } \\
\text { 6. Utilize available facilities and services } \\
\text { 7. Manage spouse without damaging the relationship } \\
\text { 8. Seek advice from right persons and right materials } \\
\text { 9. Employ a servant } \\
\text { 10. Know critical theories of work-family balance }\end{array}$ \\
\hline
\end{tabular}

Based on the above indicators, four instruments were originally developed. Levels of the instruments were interval and 5-point Likert scales were applied.

\section{Validity and Reliability of the Instruments}

The content validity of a measuring instrument (the composite of measurement scales) is the extent to which it provides adequate coverage of the investigative questions guiding the study (Cooper and Schindler, 2003). There are three main kinds of evidence in support of content validity and they are: a) the judgment of those who construct the instrument or other experts familiar with the subject area; b) detailed definition or conceptualization and operationalization of the behavioral domain or universe of interest; c) indirect way: high internal consistency reliability (Walsh and Betz, 1995 as in Opatha, 2005). There are four constructs under the study, and these requirements were met with regard to each construct satisfactorily assuring content validity. The construct validity of the variables of this study was ensured (by using the process of construct validation proposed by Schmitt and Klimoski, 1991 as in Opatha, 2005) as the correlation analysis supported the relevant hypotheses formulated linking the relationship between the dependent variable and the independent variables. 
The Cronbach's Alpha test was used in order to measure the inter-item consistency reliability. The relevant results are given in Table 1. According to the results of the test there was an adequate degree of internal reliability with regard to each of the four constructs.

Table 1: Reliability of the Instruments

\begin{tabular}{|l|l|l|}
\hline Variable & Cronbach's Alpha & N of Items \\
\hline Work-family balance & 0.797 & 13 \\
\hline Time management & 0.773 & 10 \\
\hline Nature of the spouse & 0.733 & 9 \\
\hline $\begin{array}{l}\text { Understanding the strategies available for work-family } \\
\text { balance }\end{array}$ & 0.725 & 15 \\
\hline
\end{tabular}

In order to test the external aspect of the reliability of the instruments measuring the four constructs the test-retest method was used. With test-retest, reliability was obtained by administering the instrument to the same people on two different occasions. Two considerations of the test-retest administration are memory effects and true rating changes. It was decided to have a two-week time interval between the two administrations in order to minimise the memory effects and the likelihood of true rating changes. Test-retest data were collected from 10 respondents who were selected by applying the convenient sampling method. The test-retest coefficient was 0.90 .

\section{Techniques of Data Analysis}

There were five hypotheses of the study. First hypothesis, second hypothesis, and third hypothesis were about relationships between two variables, and hence the Pearson ProductMoment Correlation technique was appropriate and then used. The fourth hypothesis is about the joint impact of the three variables on WFB, and this hypothesis was tested by using the Multiple Regression technique. As the fifth hypothesis was about testing a difference between two groups with regard to one variable, Independent Sample T Test was applied. A need of exploring the data for normality and linearity arose because the correlation tests were parametric. Exploration of the data revealed that the conditions were met reasonably.

\section{Results}

As there are three independent variables considered for the study, four hypotheses (from $\mathrm{H} 1_{\mathrm{A}}$ to $\mathrm{H} 4_{\mathrm{A}}$ ) were formulated to test the relationship between each of the variables and the degree of WFB. The joint effect of the three variables on the degree of WFB was tested by hypothesis $\left(\mathrm{H} 4_{\mathrm{A}}\right)$. The hypothesised relationships are shown in Table 2.

Table 2: Hypotheses (from $\mathrm{H} 1_{\mathrm{A}}$ to $\mathrm{H3} 3_{\mathrm{A}}$ and $\mathrm{H} 4_{\mathrm{A}}$ ) of the Study

\begin{tabular}{|l|l|l|}
\hline $\begin{array}{l}\text { No } \\
\dot{1}\end{array}$ & Hypothesised Relationship & $\mathbf{H i}_{\mathbf{A}}$ \\
\hline 2 & Time Management $\rightarrow$ Degree of WFB & $\mathrm{H} 1_{\mathrm{A}}(+)$ \\
\hline 3 & Nature of the Spouse $\rightarrow$ Degree of WFB & $\mathrm{H} 2_{\mathrm{A}}(+)$ \\
\hline 4 & $\begin{array}{l}\text { Understanding the Strategies for WFB } \rightarrow \text { Degree of WFB } \\
\text { Strategies for WFB } \rightarrow \text { Degree of WFB }\end{array}$ & $\mathrm{H} 3_{\mathrm{A}}(+)$ \\
\hline
\end{tabular}


$\mathrm{Hi}_{\mathrm{A}}$ stands for the alternative hypothesis and + stands for a positive relationship between the independent variable and the dependent variable. The three hypotheses (from $\mathrm{H} 1_{\mathrm{A}}$ to $\mathrm{H} 3_{\mathrm{A}}$ ) have been postulated to be directional hypotheses and they are positive in nature.

The results of Pearson's Product Moment Correlation that was used to test the null hypotheses for the three hypotheses (from $\mathrm{H} 1_{\mathrm{A}}$ to $\mathrm{H} 3_{\mathrm{A}}$ ) are shown in Table 3 . As a 95 percent confident level is desired, the level of significance $(\propto)$ is .05 . Because all the three hypotheses were bivariate that were concerned with a positive relationship $\left(\mathrm{H}_{\mathrm{A}}>0\right)$ it was decided to use one-tailed test. As can be seen, the correlation coefficients of time management and understanding the strategies for WFB were significant at $\mathrm{p}<.01$. The correlation coefficient of nature of the spouse was significant at $\mathrm{p}<.05$. Hence it was possible to reject the null hypotheses pertaining to these three variables. This means that the hypothesised relationship (positive) between each of the three variables and the degree of WFB was supported by the data. Thus, there is statistical evidence to substantiate the hypothesised positive relationship between each of the three variables and the degree of WFB.

Table 3: Pearson Correlation Coefficients for the Three Variables

\begin{tabular}{|l|l|l|l|}
\hline No & Variables & Coefficient & Sig \\
\hline 1 & Time Management & $.323^{* *}$ & .001 \\
\hline 2 & Nature of the Spouse & $.206^{*}$ & .022 \\
\hline 3 & Understanding of the Strategies for WFB & $.385^{* *}$ & .0005 \\
\hline
\end{tabular}

$* \mathrm{p}<.0 .05 \quad * * \mathrm{p}<.0 .01 \quad \mathrm{n}=96$

The fourth hypothesis formulated for the study was that time management, nature of the spouse, and understanding the strategies available for WFB will jointly and significantly explain the variance in the degree of WFB. The test of this hypothesis leads to accomplish the third objective of this research study, i.e., to establish that these three factors have a significant positive joint impact on work-family balance. Table 4 presents the relevant results of the multiple regression test.

Table 4: Combined Impact of the Three Variables on Degree of WFB

\begin{tabular}{|l|l|l|l|l|l|}
\hline $\mathrm{R}$ & R Square & $\begin{array}{l}\text { Adjusted } \\
\text { R Square }\end{array}$ & $\begin{array}{l}\text { Std.Error of } \\
\text { the Estimate }\end{array}$ & F Value & Sig. F \\
\hline .426 & .181 & .155 & 9.30803 & 6.796 & 0.000 \\
\hline
\end{tabular}

According to the results it shows that the multiple regression coefficient (R) of the three independent variables and the degree of WFB was .426 and the R Square was .181. R Square is significant at 0.01 as $\mathrm{F}$ value is 6.796 with an observed significant value of .0005 which is less than 0.05 as well as 0.01 . Also it indicates that about 18 percent of the variance (R Square) in the degree of WFB has been significantly explained by the three independent variables together substantiating the alternative hypothesis $\left(\mathrm{H}_{\mathrm{A}}\right)$ while rejecting the relevant null hypothesis. Therefore, there is statistical evidence to claim that time management, nature of the spouse, and understanding the strategies available for WFB jointly and significantly explain the variance in the degree of WFB. 
The fifth hypothesis formulated for this study was that there is a significant difference between male accounting professionals and female accounting professionals with regard to WFB. Relevant null hypothesis is that there is no difference between male accounting professionals and female accounting professionals with regard to WFB. Interdependent Sample T Test was the appropriate statistical technique in order to test the hypothesis and the desire level of significance is 0.05 (95\% confident level). The alternative hypothesis was a non directional one, and therefore two-tail test was applied. The results of the independent sample test are shown in the following Table.

Table 5: Independent Sample T Test of Gender and WFB

\begin{tabular}{|l|l|}
\hline & Value \\
\hline Mean-Male & 4.1111 \\
Mean-Female & 4.2619 \\
t (Equal variances assumed) & 1.011 \\
t (Equal variances not assumed) & 1.040 \\
Mean difference & -.15079 \\
df (degree of freedom) & 94 \\
Sig (2-tailed) & .315 \\
\hline
\end{tabular}

According to the relevant descriptive statistics, i.e. the mean value there is a difference between male accounting professionals and female accounting professionals with regard to the degree of WFB. It suggests that degree of WFB of female accounting professionals is greater than that of male accounting professionals. In order to find out whether this difference is statistically significant or not Independent Sample T Test was used. Results of the Independent Sample T Test show that Levene's test for equality of variances is not significant with $\mathrm{F}=2.662$ (sig .106). It is not possible to reject the null hypothesis that the two samples come from populations with the same variances. Therefore, $\mathrm{T}$ Test for equal variances are assumed was considered (Norusis, 1997). The $\mathrm{T}$ value for equal variances assumed is 1.011 that was not significant at $95 \%$ confident level ( $\mathrm{sig}=0.315$ is higher than 0.05 ). Since the $t$ value is statistically not significant, the relevant null hypothesis cannot be rejected. Therefore the alternative hypothesis is not accepted. Thus there is no statistical evidence to claim that the degree of WFB of male accounting professionals is significantly different from that of female accounting professionals. Thus, degree of WFB does not get differed owing to the gender as far as this study is concerned.

\section{Discussion}

Time management was found to be significantly and positively related to the degree of WFB. It was hypothesized that time management has a significant and positive relationship with WFB of Sri Lankan accounting professionals. If time management is not done properly by the accounting professional, it is not possible to have good WFB. In other words poor time management influences the professional to have poor WFB. Poor WFB means work-family conflicts and family-work conflicts. This empirical finding is in line with the argument given by Nelson and Lyubomirsky (2015) that imbalance occurs when work life and home life directly conflict with one another, due to toiling long hours and an inability to meet commitments at home, or to spending too much time at home, resulting in a failure to complete responsibilities at work. Greenhaus and Beutel (1985) state that work-family conflict exists when time devoted to the requirements of one role makes it difficult to fulfill the requirements of another. And therefore 
time management becomes an important factor in balancing work and family lives. Further he explains that work schedules, work orientation, marriage, children, and spouse employment patterns may all produce pressures to participate extensively in the work role or the family role. Conflict is experienced when these time pressures are incompatible with the demands of the other role domain.

A significant positive relationship between nature of the spouse and WFB was found. It was hypothesized that the more positive the nature of the spouse, the higher the WFB is. If the spouse is understanding and supportive, the more the other partner balances his/ her work and family lives. This finding is compatible with the findings of some researchers. Adams, Lynda, and Daniel (1996) found that a negative relationship existed between family instrumental support and work-family conflict and this supports the present model in that family support is a predictor of work-family conflict. Spouse support was significantly and negatively related to parental time commitment also. Another research conducted by Fathima and Sahibzada (2012) found partner support as a major determinant to achieve work-family balance in their research conducted by using the university teachers in Pakistan. Accordingly they concluded that there is a significant difference in work-life balance of male and female university teachers with respect to partner support. Longer work hours by husbands also have been shown to be associated with greater marital conflict and less balance in work and family lives (Jeffrey, Hawkins, Ferris, and Weitzman, 2004). Also to support this finding, Young and Melissa (2013) reported that the husband's social support buffered the relationship between wife's job stressors and their workfamily balance.

It was found that understanding the strategies available for WFB and WFB were significantly and positively correlated. Also further analysis of the data of this research reveals that understanding of the strategies available for work-family balance was the most important predictor to work-family balance among the three variables identified under the framework. Nowadays organizations more and more tend to provide family-friendly policies to its employees, having understood the consequences of not having a work-family balance. But Ellen \& Cynthia (1999) argue that since many are not aware of these strategies available, they are underutilized and employees are not taking advantage of them to smooth their lives. Therefore this research identified understanding of strategies available for work-family balance as a major factor to achieve WFB. Also from the responses received from the selected sample, it was found that understanding has a significant positive effect on work-family balance.

It was found that there was no significant difference between male accounting professionals and female accounting professionals with regard to the degree of WFB. As far as this study is concerned there is no statistical evidence to accept the fifth hypothesis (there is a significant difference between male accounting professionals and female accounting professionals with regard to WFB) and it was rejected. This suggests that it is unlikely that gender influences the degree of WFB. This might be due to the reason that both male and female accounting professionals are equally aware of that WFB is necessary for their well-being and success of life. According to univariate analysis of this study, none of the respondents had one (very low) in the five point Likert scale, and had a good degree of WFB (mean=4.1711) meaning that almost all the respondents were good at maintaining WFB having understood the concept, time management and getting the support from the spouse. Also it might be owing to the reason that 
majority of female accounting professionals do not have heavier workload at home compared with that of male accounting professionals (having one child or two children).

\section{Conclusion}

Accounting professionals are a critical category of employees in achieving success and progress of success of all types of organizations. This research examined a sample of accountancy professionals in Sri Lanka to reveal major dynamics of their work-family balance. Time management, nature of the spouse and understanding the strategies available for work-family balance are positively and significantly related to degree of work-family balance of accounting professionals in Sri Lanka. Also time management, nature of the spouse and understanding the strategies available for work-family balance will have a positive significant joint impact on work-family balance. Hence the accounting professionals, particularly young new accounting professionals who wish to have a good balance between work life and family life need to be concerned with the three major factors investigated. Organizations need to pay a considerable concern on time management, nature of the spouse and understanding the strategies available for work-family balance when performing their training and development function with regard to accounting professionals. The paper provides an empirical evidence of a major predictor of work-family balance of accounting professionals, i.e. understanding the strategies available for work-family balance. Further research is suggested in respect of testing the research framework for other categories of employees including university teachers, general managers, engineers, and doctors. Also a further expansion can be done to investigate intervening variables which may have mediating effects on the relationship between understanding the strategies available for work-family balance and degree of work-family balance.

\section{References}

Adams G.A., Lynda A.K. and Daniel W.K., (1996), Relationships of job and family involvement, family social support, and work-family conflict with job and life satisfaction, Journal of Applied Psychology, Vol. 81, pp. 411-420.

Akuratiyagamage, V.M. and Opatha, H.H.D.N.P. (2004), Grievances of middle managers: an empirical investigation into perceptions of commercial bank branch managers in Sri Lanka, Journal of Management Research, Faculty of Management Studies, University of Delhi, 4: 2, August, pp. 99-112.

Cooper, D.R. and Schindler, P.S. (2003), Business Research Methods, $8^{\text {th }}$ ed., New Delhi: Tata McGraw-Hill Publishing Company Limited.

Dupree, D. and Marder, M. (1984), Principles of Accounting, California: Addison-Wesley Publishing Company.

Ellen E. and Cynthia O. (1999), Bridging the work-family policy and productivity gap: A literature review, Community, Work \& Family, Vol. 2, pp. 7-32.

Fatima N. and Sahibzada S.A., (2012), An Empirical Analysis of Factors Affecting Work Life Balance among University Teachers: the case of Pakistan, Journal of International Academic Research, Vol. 12, No. 01, pp. 16-29.

Greenhaus, J. and Beutell, (1985), Sources of conflict between work and family roles, Academy of Management Review, Vol. 10, pp. 76-88.

Jeffrey H.E. , Hawkins, M., Ferris, M., and Weitzman, M. (2001), Finding an Extra Day a Week: The Positive Influence of Perceived Job Flexibility on Work and Family Life Balance, Family Relations, Vol. 50, pp. 49-58. 
Lowe, G. (2006), Under Pressure. Implications of Work-Life Balance and Job Stress, Human Solutions Report, Wilson Banwell PROACT.

McFarland, L.A. (2004), Work-Family Balance, The Industrial Organizational Psychologist, Vol.41, No.4, pp. 47-53.

McShane, S.L., Glinow, M.A.V. and Sharma, R.R. (2008), Organizational Behaviour, New York: McGraw-Hill (Indian Edition).

Nelson, S.K. and Lyubomirsky, S. (2015), Juggling family and career: parents' pathways to a balanced and happy life, BURKE 9781783474097 PRINT (M3606) (G).indd 100.

Opatha, H.H.D.N.P. (1994), Employee Grievance Settlement Procedure: A Case Study of Two Corporations, Management Review, Faculty of Management Studies and Commerce, University of Sri Jayewardenepura, Sri Lanka, 1, 2: pp.53-60.

Opatha, H.H.D.N.P. (2005), An Empirical Investigation of Union-related Factors Contributing to Labour-Management Relationship in Manufacturing Firms in Sri Lanka, Sasin Journal of Management, Vo. 11, No. 1, pp.85-102.

Opatha, H.H.D.N.P. (2009), Human Resource Management: Personnel, Colombo: Department of HRM, University of Sri Jayewardenepura.

Opatha, H.H.D.N.P. (2010), Personal Quality, Dept of HRM, University of Sri Jayewardenepura.

Opatha, H.H.D.N.P. and Teong, L.K. (2014), Enhancing Personal Q, Sintok: Penerbit Universiti Utara Malaysia.

Rantanen, J., Kinnunen, U., Mauno, S., and Tillemann, K (2011), Introducing Theoretical Approaches to Work-Life Balance and Testing a New Typology Among Professionals, S.Kaiser et al (eds.), Creating Balance?, DOI 10.1007/978-3-642-16199-5_2, (C) Springer-Verlag Berlin Heidelberg 2011.

Robbins, S.P. and Judge, T.A. (2013), Organizational Behavior, $15^{\text {th }}$ edi, Boston: PEARSON.

Sekaran, U. (1992), Research Methods for Business: A skill-building approach, $2^{\text {nd }}$ ed, New York: John Wiley \& Sons, Inc.

Senecal, C., Vallerand, R.J., and Guay, F. (2001), Antecedents and Outcomes of Work-Family Conflict: Toward a Motivational Model, PSPB, Vol. 27, No. 2, pp.176-186.

Smith, J. And Gardner, D. (2007), Factors Affecting Employee Use of Work-Life Balance Initiatives, New Zealand Journal of Psychology, Vol. 36, No.1, pp. 3-12.

St-Amour, N., Laverdure, J., Devault, A., and Manseau, S (2007), The Difficulty of Balancing Work and Family Life: Impact on the Physical and Mental Health of Quebec Families, Institut National De Sante Publique Du Quebec.

Werther, B. W., Davis, K., Shwind, H. F., Das, H. and Miner, F. C. (1985), Canadian Personnel Management and Human Resources, $2^{\text {nd }}$ ed, Toronto: McGraw- Hill, Reversion Ltd.

Young M.S.S. and Melissa A.M., (2013), Spouse's Work-to-family Conflict, Family Stressors, and Mental Health among Dual-earner Mothers and Fathers, Society and Mental Health.

Zikmund, W.G. (1997), Business Research Methods, $5^{\text {th }}$ ed, Fort Worth: Harcourt Brace College Publishers. 